\title{
The Civil War in a Bottle: Battle at Fayetteville, Arkansas
}

\section{Author: Kim Allen Scott}

"This is the final version of record of an article that originally appeared in Arkansas Historical Quarterly in September 1995."

Scott, Kim Allen. "The Civil War in a Bottle: Battle at Fayetteville, Arkansas." Arkansas Historical Quarterly 54, no. 3(Autumn 1995): 239-68.

Made available through Montana State University's $\underline{\text { ScholarWorks }}$ 


\title{
The Civil War in a Bottle: Battle at Fayetteville, Arkansas
}

\author{
KIM ALLEN SCOTT
}

THE TERRIFYING MORNING of April 18, 1863, seemed like an eternity for Sarah Yeater as she cowered in a,damp Fayetteville cellar. Muffled sounds of rapid gunfire, shouting men, and jingling harnesses coming from the yard above caused Sarah to tremble violently as she hugged her three-year-old son Charley and stared wild-eyed at the other civilians who huddled with her in the darkness. Sick with ague and five months pregnant to boot, Sarah had ample reasons for trembling beyond the sounds of battle raging overhead, yet an additional shock to the young housewife's nerves was about to be cruelly delivered. As Sarah rose from her mattress to speak to her sister-in-law, Sallie, the cellar rang from the sudden concussion of an artillery shell. The missile shattered the jamb of the basement door, knocked down fragments of brick and mortar from the chimney in the kitchen above, and cracked in two a large iron kettle of lye that rested on the hearth. Choking with dust and screaming in terror, the helpless women and children saw the flash of the iron shell as it bounded rapidly into their midst and just as suddenly disappeared. Sarah could not have known it at the time, but the broken kettle in the kitchen had actually saved her and the others from certain death: the lye had miraculously extinguished the fuse an instant before the projectile dropped down to the refugees below. ${ }^{1}$

Kim Allen Scott is special collections librarian at Montana State University. This article won the 1994 Arkansas Historical Association's Lucille Westbrook Award for Local History.

THE ARKANSAS HISTORICAL QUARTERLY

VOL. LIV, NO. 3, AUTUMN 1995 
The battle of Fayetteville, Arkansas, may have seemed like an apocalyptic struggle to Sarah Yeater from her cellar vantage point that April morning in 1863, but more than 131 years later it leads most modern readers to ask why it warrants anything more than a minor footnote to the study of Civil War history. It was hardly a decisive engagement, and with so few participants it may not qualify as a battle at all. Almost no one involved became especially prominent, either during the war or afterwards, and compared with other clashes in the Trans-Mississippi, primary source material on the battle of Fayetteville has been relatively scant until the recent discovery of some longneglected documents. ${ }^{2}$

But in many ways this little fight in the Ozark mountains of northwest Arkansas can be considered as a microcosm of the Civil War itself. Just like the hobbyist who painstakingly builds a ship in a bottle that replicates a full-scale vessel, a historian can closely examine the battle of Fayetteville to illustrate many facets of the larger conflict. For example, the concept of a true civil war, with brother killing brother, is evident in the battle of Fayetteville. The 1st Arkansas Cavalry (Union) met the 1st Arkansas Cavalry (Confederate) at Fayetteville, and while Sarah Yeater worried that morning about her husband serving in the Confederate ranks, her sister-in-law, Sallie, may have reflected on the safety of a Union officer whom she later married. The Civil War's notorious reputation as the first conflict to actively involve large numbers of civilians in the maelstrom is certainly shared by the Fayetteville experience. Non-combatants in the town suffered forced removal from residences, physical assaults, and at least one death during the spring of 1863. From the standpoint of overall war strategy, the battle of Fayetteville represents a miniature version of the greater conflict's opening years. The southern commander's approach to the field is reminiscent of Stonewall Jackson's maneuvers during the Valley Campaign, and like McClellan at Antietam and Meade at Gettysburg, the Federal commander at Fayetteville felt too weakened by a stalemate

'Sarah J. Yeater, “Civil War Experiences of Sarah J. Yeater" (Sedalia, MO, 1910), 19-28, typescript in Special Collections, University of Arkansas Library, Fayetteville.

${ }^{2}$ The exceptions are Albert W. Bishop, who became president of Arkansas Industrial University, and William Lewis Cabell, who served as mayor of Dallas, Texas. 
victory to follow up his battlefield success. The struggle at Fayetteville also serves as an excellent example of the tactical and technological factors that won the war for the North. Fortifications, rifled guns, and an unfortunate willingness by many Civil War commanders to employ obsolete battlefield maneuvers are all to be seen in this story. Finally, the pathos of the Civil War with its tragic and unnecessary loss of life is also the sad lesson of Fayetteville's ordeal.

During the opening months of 1863 , the town of Fayetteville had seen quite enough of the Civil War. Since the battle of Wilson's Creek in 1861 right up to the opening movements of the Pea Ridge campaign in 1862, the Confederate army had stored supplies in Fayetteville's abandoned schools, housed sick soldiers in private homes and businesses, and even established a newspaper office in the town's courthouse. A brief push south by Union forces commanded by Brig. Gen. Alexander Asboth on February 18, 1862, brought the cruel realities of war home to Fayetteville, because the Rebels burned most of the town's business district before retreating south. Shortly before the conflagration the Confederates went on a looting rampage as well, sacking homes and stores with the assistance of a few civilians who got swept up in the passions of the moment. ${ }^{3}$ General Asboth occupied Fayetteville the next day and set up his headquarters in Judge Jonas Tebbetts' house, a structure that remains intact to the present day. Tebbetts, a New Hampshire native and one of the town's staunchest Unionists, openly welcomed the invaders by bringing out an American flag he had been hiding for the previous few months. (We can only imagine the judge's horrified disappointment when General Asboth, after reading a proclamation to the Union people on February 23 guaranteeing their safety, promptly retreated as the Rebels returned in force.) $)^{4}$ The Yankees did not return to Fayetteville for a stay of any noteworthy length until December 6,1862, when the second and third brigades of the Army of the Frontier passed through the town on their way to the battle of Prairie

\footnotetext{
${ }^{3} \mathrm{Kim}$ Allen Scott, "Witness for the Prosecution: The Civil War Letter of Lieutenant George Taylor," Arkansas Historical Quarterly 48 (Autumn 1989): 260-271.

"The War of the Rebellion: A Compilation of the Official Records of the Union and Confederate Armies, 128 vols. (Washington, D.C.: GPO, 1880-1901) ser. I, vol. 8, 70-71; cited hereafter as OR.
} 
Grove. In the weeks following that contest, many Union regiments occupied Fayetteville, including the newly organized 1st Arkansas Cavalry, who helped establish barracks, munitions offices, and hospitals in buildings spared by the earlier burnings.

Col. M. LaRue Harrison, a former officer with the 36th Illinois Infantry, commanded the 1st Arkansas Cavalry. The regiment's rank and file consisted of loyal northwest Arkansas men who had opposed the secessionists in various means since the war began, but many of the officers, like Colonel Harrison and his brother, Lt. Elizur B. Harrison, came from other northern regiments seeking an easy opportunity for promotion. (Nepotism hardly seemed to be a major concern in these appointments: even Colonel Harrison's twelve-year-old son, Edward, got a position in the regiment as bugler for company F.) Unfortunately for the reputation of the 1st Arkansas Cavalry, a detachment from the regiment served as an advance for Brig. Gen. Francis Herron's column at the battle of Prairie Grove. When the Confederate cavalry overran the troopers early on the morning of December 7, 1862, the Arkansas Federals ran as fast as they could in the opposite direction, and General Herron actually had to shoot one of the panic-stricken cavalrymen out of the saddle in order to stop the stampede. ${ }^{5}$ As a result of this incident, not many people, North or South, had much confidence in the fighting abilities of Arkansas Union troops.

Although the Army of the Frontier used Fayetteville as their base immediately following the fight at Prairie Grove, the bulk of the Union forces left for duty in southwest Missouri and the Indian Territory in early January 1863 . This left the town under the sole protection of Colonel Harrison's regiment, some companies of the 10th Illinois Cavalry, and the newly formed 1st Arkansas Infantry and 1st Arkansas Light Artillery.

Representing the Civil War's lengthy record of unpleasant civilian confrontations with the military are several incidents which occurred at Fayetteville shortly before the battle. The odyssey of the Yeater family in their search for shelter proved to be a first in the chain of events that placed Fayetteville civilians directly in harm's way. Sarah Yeater, a

${ }^{5}$ OR, ser. I, vol. 22, pt. 1, 102-103. 
former schoolteacher from Osceola, Missouri, moved to Fayetteville in May 1862 with her toddler son, Charley, sister-in-law, Sallie, and mother-in-law. The elder Mr. Yeater had died prior to their arrival in town, and Sarah's husband, John, had ridden off in December to join the Confederate army, leaving the two households of women and children essentially without protection. At first the two branches of the Yeater family were comfortably situated in adjacent rented houses on the west side of Cassville Road, but when Jonas Tebbetts and his family left Fayetteville in November 1862, Sallie and her mother moved to the judge's spacious home on the north side of Old Missouri Road. ${ }^{6}$ Meanwhile, Colonel Harrison cast a covetous eye on Sarah's house and abruptly commandeered the place for his own family and himself, relegating Sarah, Charley, and their servant to a single room in the back. Sarah endured the invasion for three days as she watched her yard turn into a military camp and the Harrison family use her china, silverware, and furniture. Finally she fled across the street to join her in-laws at the Tebbetts house. For two weeks the reunited Yeater family enjoyed living in one of Fayetteville's finest remaining houses, but Colonel Harrison once again decided his own needs superseded that of the Yeaters. He forced the family from the Tebbets house into a dingy, four-room shack in the backyard of a large home on the south side of Old Missouri Road directly across from the Tebbetts house. The Yeaters would spend the remainder of the winter in those cramped quarters, and on April 18 their home would serve as cover for attacking Confederate troops. ${ }^{7}$ Even though the new Union regiments at Fayetteville consisted overwhelmingly of Arkansas men, many people of the town suffered what they considered rather harsh treatment regardless of their political leanings.

'In order to minimize the use of modern place names in this paper I will substitute, whenever possible, the 1863 designation for geographic features. Cassville Road was the name used for modern-day College Avenue, and Old Missouri Road followed the present route of Dickson Street in Fayetteville.

7Yeater, "Civil War Experiences," 19-21. The precise location of Sarah's first home is confirmed by a deed dated August 28, 1862, transferring ownership of the dwelling from Edward Peer to James W. Stirman. In the document Peer declares the "premises recently occupied by myself and now recently by William Lane, and now in occupancy of Mr. Yeater." (Washington County Deed Book "P”, 67.) 
For example, Colonel Harrison demanded on January 14 that everyone take a loyalty oath or be considered traitors, and on January 23 he ordered all able-bodied men to report for work details in Fayetteville to help construct fortifications. ${ }^{8}$ In response to the labor demand, at least one resident felt as if he had already amply supported the Union cause. William Baxter, an unapologetic Unionist who had remained in Fayetteville since the war began, never reported for Colonel Harrison's mandated spadework. As an alternative to digging, Baxter, a former college instructor and preacher, volunteered his services as a nurse in one of the hospitals established in Fayetteville immediately following the fight at Prairie Grove. The preacher worked diligently among the unfortunate men for weeks and only retired to his home after Drs. Ira Russell and Seymour D. Carpenter arrived from St. Louis on December 21 to take charge of the town's hospitals. ${ }^{9}$

The time passed slowly for the idled Baxter. The college building just south of his house in which he once taught had burned to the ground the year before, and the congregation to which he once preached had long ago scattered. One afternoon in early February as he looked out his front window, Baxter saw two Federal cavalrymen dismantling part of the fence surrounding his front yard. Baxter had received a written safeguard the past December from Maj. Gen. John Schofield as a reward for the preacher's good services in the hospitals, and he naively thought the document would protect his property from despoliation. Boldly walking out from his front door, Baxter confronted the two soldiers and demanded that they leave his fence alone. The preacher thought the incident settled, but before he could return to his sitting room he was met by Lt. Crittenden C. Wells of the 1st Arkansas Cavalry. "Are you the one who told my men to leave that fence alone?" growled Wells. Baxter barely had time to answer that he was before the lieutenant grabbed him

${ }^{8}$ M. LaRue Harrison, General Order No. 4, January 14, 1863, General Order No. 8, January 23, 1863, "Regimental Record Books, Volunteer Organizations in the Civil War. Union Regiments from Arkansas State," microform, RG 94, First Regiment, Arkansas Calvary, Regimental Order Book, 1862-1866, National Archives; cited hereafter as Regimental Records.

Seymour D. Carpenter, Genealogical Notes of the Carpenter Family (Springfield, IL: Illinois State Journal Co., 1907), 139. 
by the beard and thrust a revolver under his nose. Threatening to blow off Baxter's head, Wells began cursing the preacher while cocking the weapon. Baxter tried to remain completely still lest the pistol accidentally discharge. He asked Wells to take him to Colonel Harrison. Lieutenant Wells uncocked the pistol and turned it butt forward in his hand, loudly assuring Baxter that he knew him to be a Rebel and intended to pistol whip him. When Baxter offered to show Wells his written safeguard, the surly officer released the preacher and allowed him to return home. The moment Baxter entered his front door and saw that his family had witnessed the confrontation, he "trembled in every limb" to think how close he had come to being killed. And so, after all the horror he had witnessed since the war began, William Baxter finally decided to leave Fayetteville on February 9, 1863. ${ }^{10}$ He eventually settled with his family in Cincinnati, Ohio, where he spent the remainder of the war writing a vivid reminiscence of his experiences and eventually resumed his occupation as a man of the cloth.

Baxter's old house in Fayetteville did not remain empty for long though. The family of another Missouri Confederate, Joseph Davis, moved into Baxter's comfortable quarters immediately after his departure. Like John Yeater, Joseph Davis had left his family while he served with the southern army, and Mrs. Davis, her sister, and four daughters had only Joseph's brother Ben remaining at home for their protection. And also like the Yeaters, the Davis family found that they could not keep the Yankees out of their house. With such a desirable location directly across the street from his brother's headquarters, Lt. Elizur B. Harrison took a room of the Davis house while he performed the duties of mustering officer for the 1st Arkansas Cavalry, and several other soldiers moved in as well. Now the Davis family, like the Yeaters who lived in their backyard, would soon find themselves right in the epicenter of the approaching battle. ${ }^{11}$

${ }^{10}$ William Baxter, Pea Ridge and Prairie Grove (Cincinnati: Poe and Hitchcock, 1864), 227-231.

${ }^{11}$ E. B. Harrison, "The Battle of Fayetteville," Flashback 18 (April 1968): 17; Yeater, "Civil War Experiences," 19-21. Harrison's article is a printed version of a speech he delivered in June 1926 at the dedication of a monument at the battle site. 
Knowledge that an attack from the Confederates could be expected any day became common to both military and civilian residents as April approached. The official records are full of letters from Colonel Harrison in the early spring of 1863 begging for more supplies for his garrison and letters to the colonel from his superiors ordering fortifications constructed in the town but promising little in the way of ammunition or reenforcements. Nothing summarizes the state of affairs in the town better than one missive from Harrison dated April 1, 1863:

The First Arkansas Cavalry numbers an aggregate of 1,032 men, probably when all are at the post they may number 850 effective men. They have 154 serviceable horses and 65 unserviceable, all told. The regiment has not received any clothing for three months, and only a very small supply since November, so that a large part of the men are in a destitute condition. The First Arkansas Infantry will number in a few days an aggregate of 830 men, probably 700 of them effective. They are totally without transportation, clothing, or tents or equipments of any kind, except the arms picked up on the Prairie Grove battle ground, which are of all patterns and calibers. The destitution of clothing is very great, and much suffering and sickness prevails on account of it. Besides, it would be a ruinous policy to place this undrilled, barefooted, butternut regiment in the field to be mixed up with and cut in pieces by Rebels in the same dress. The First Arkansas Light Artillery numbers 110 men, who are destitute of clothing, and have never received their guns. Of course, nothing can be expected of them. ${ }^{12}$

The constant demands of sending mounted patrols into the surrounding countryside kept the actual force present for duty at Fayetteville on any given day to much less than the above reported garrison strength of 1,972. Just a week prior to the battle, the post returns show only 533 officers and men from the 1st Arkansas Cavalry present, 578 from the

${ }^{12}$ OR, ser. I, vol. 22, pt. II, 192. 
1st Arkansas Infantry, and the entire 1st Arkansas Light Artillery absent. ${ }^{13}$

What Colonel Harrison's force lacked in numbers they may have made up for in armament. The presence of rifled small arms in Civil War battles has been blamed by many historians for unusually heavy casualties during the war's opening months and for the ubiquitous appearance of entrenchments towards the end of the conflict. The situation at Fayetteville reflects this larger picture of the Civil War because many of the Union cavalry troopers had an advantage over their poorly armed Confederate adversaries. While not all the Federal troopers had .58 calibre Whitney and Springfield carbines (many of the men still carried .69 calibre smoothbores), enough of the rifled weapons were present that April to give Harrison's men the tactical edge. The Federal small arms would demonstrate their worth during the coming battle when killing shots would be delivered at ranges up to four hundred yards. The Rebels carried little more than shotguns and sabers, weapons which demanded closing with the enemy at suicidal distances in order to be effective.

If Colonel Harrison entertained any doubts about the intentions of the Rebels, an announcement in March from Confederate Brig. Gen. William L. Cabell telegraphed the southerner's impending strike in Washington County. Cabell took command of all Rebel forces in Northwest Arkansas that month and fired off a belligerent proclamation to mark his ascendancy to power:

In obedience to special orders form Headquarters Trans-Mississippi District, I this day assume command of all the troops, of whatever kind, in North West Arkansas. In doing so I hope to be able in a short time to rid that section of the state of the presence of an insolent and unscrupulous abolition invader. To do this I must have the hearty cooperation of the citizens and the united and determined effort of the soldier. . . . The enemy must be driven from the soil of Arkansas and beyond the borders of Missouri. The war has now

${ }^{13}$ "Returns from U.S. Military Posts, 1800-1916," National Archives Microform Publications, Microcopy No. 617, April 10, 1863. 
assumed such vast proportions and is being prosecuted with so much vigor that it cannot in the nature of things be of long duration. One united and vigorous effort on the part of the soldiers in Arkansas will expel the invader. He will not return. ${ }^{14}$

Cabell's conviction that the Federal army would be driven out of Arkansas with a determined push came partially from recent experience. A January 1863 raid on Springfield, Missouri, by Rebel forces under Brig. Gen. John S. Marmaduke resulted in the Union troops temporarily abandoning many positions in Arkansas and the Indian Territory in order to strengthen their presence in southwest Missouri. Now with rumors that the Fayetteville garrison would be providing support for other Federals in the Indian nations, Cabell correctly assumed an attack on the Union army's southernmost outpost would cause the entire Army of the Frontier to again retreat to its support in Springfield.

Unfortunately for the Confederates, Cabell relied on faulty intelligence when planning his attack on Fayetteville. While he gathered his forces at the Arkansas River valley town of Ozark during the opening days of April, Cabell received biased reports from southern sympathizers that both amplified the desire of some Fayetteville citizens to be rid of their "northern oppressors" and diminished estimates of the garrison's strength. The Rebel commander also misinterpreted the only two accurate pieces of information his spies provided. He knew that, with the recent withdrawal of the 10th Illinois Cavalry, only Arkansas troops remained at Fayetteville, and that the garrison had no cannon. Cabell felt confident that the Arkansawyers would prove just as cowardly as they had at Prairie Grove, and that without artillery support, the Yankee troopers would scatter like quail once he opened up with his own field pieces. ${ }^{15}$

On the morning of Thursday, April 16, 1863, General Cabell, with a mounted force of nine hundred men and two six-pound howitzers, left Ozark on the expedition to Fayetteville. The Rebel forces consisted of a conglomeration from several available area units including both regular

\footnotetext{
${ }^{14}$ Albert W. Bishop, Loyalty on the Frontier; or Sketches of the Union Men of the South-West (St. Louis: E.P. Studley, 1863), 210-211. Bishop's reprinting of Cabell's proclamation is its earliest extant printed form.

${ }^{15}$ OR, ser. I, vol. 22 , pt. $1,310-313$.
} 
Confederate troops and a motley assortment of guerrillas. Monroe's and Carroll's Arkansas cavalry regiments (both of which were designated as the 1st Arkansas Cavalry by the southerners at varying times during the war) were joined by a company from Parsons' Texas Cavalry Brigade and a few veterans from the 1st Arkansas Mounted Rifles. Captain William Hughey commanded the artillery unit, and the men who served the guns almost all hailed from Fayetteville area. The guerrillas from northwest Arkansas who completed the forces with Cabell included those led by William "Buck" Brown, Peter Mankins, and a Captain Palmer. ${ }^{16}$

The southern commander's approach to Fayetteville mimicked on a small scale the maneuver of Stonewall Jackson in the Shenandoah Valley during 1862. Just as General Jackson used Massanutten Mountain to screen his army's rapid movements and appear unexpectedly before the enemy, General Cabell took advantage of the rugged Boston Mountains to conceal his force's movements for a surprise attack. Cabell had his choice of several roads leading to Fayetteville, and his scouts likely informed him that following the most direct route would result in a confrontation with mounted Union patrols. The advice proved accurate, for that very same afternoon Colonel Harrison sent Lt. Joseph S. Robb and most of Company $L$ down the Ozark road from Fayetteville to see what the Rebels were up to. The road Robb and his men took roughly followed the path of modern-day Highway 21, pointing southeast out of Fayetteville along the east fork of the White River and turning directly south through Fly Gap before crossing the Mulberry River north of Ozark. In order to avoid detection by Robb's patrol, Cabell's force left Ozark by travelling almost due west for a time, crossing the Mulberry River before angling northwest to intersect the Frog Bayou River and link up with the Van Buren-Fayetteville road. The Rebels crossed the Boston Mountains and followed the upper reaches of the west fork of the White River, pausing to rest for most of the afternoon of the seventeenth, and then tried a final push after nightfall in order to arrive at Fayetteville before the dawn of Saturday, April 18. The ruse worked, for Lieutenant

\footnotetext{
${ }^{16} O R$, ser. I, vol. 22, pt. 1, 307. Although Harrison lists in detail the units on the Confederate side, Cabell only mentions them in passing. A check of individual names in the index to Compiled Service Records of Arkansas Confederate soldiers shows that remnants of the First Mounted Rifles also served in Cabell's expedition.
} 
Robb arrived back at Fayetteville on Friday afternoon reporting no Rebel activity at all from the direction of Ozark. ${ }^{17}$

Adverse weather conditions interfered with Cabell's timetable. When the Rebel column reached a point about twenty miles south of Fayetteville, a cold rainstorm hit, forcing a temporary halt. ${ }^{18}$ This delay would prevent the Confederates from deploying for their attack until nearly sunrise, but another circumstance also robbed Cabell of the opportunity of completely surprising the Federal garrison. Once the weather cleared enough for the advance to continue, Rebel scouts discovered a lively wedding party at a home in the West Fork area with several Union soldiers in attendance. Lt. Gustavus F. Hottenhauer of Company B, 1st Arkansas Cavalry, had left his post at Fayetteville along with eight enlisted men. The troopers had slipped away to the wedding without permission, probably feeling quite safe in doing so after Lieutenant Robb's report of no enemy movements from Ozark. One can easily picture Hottenhauer's consternation when a call to surrender stopped the wedding dance. Most of the soldiers in attendance gave up quietly, but the lieutenant himself may have attempted to hide before being taken into custody. ${ }^{19}$

The Rebels pushed on after collecting their first prisoners. As they neared Fayetteville the column veered off to the east in order to take advantage of a large ravine which cut diagonally across the western slope

${ }^{17}$ lbid., 306.

${ }^{18}$ OR, ser. I, vol. 22, pt. 1, 310-311; Little Rock True Democrat, April 29, 1863.

${ }^{19} \mathrm{An}$ interesting bit of folklore has grown up around this incident. In all contemporary accounts of the capture the lieutenant is not identified, nor is Hottenhauer mentioned in any part of the First Arkansas Regimental Records as ever having been captured or AWOL. His compiled service record is also silent on the subject. The only source mentioning him as the unfortunate commander of the captured dancers is from a Depression-era reminiscence of a West Fork resident interviewed by Bernice Karnes. Karnes's version has Hottenhaver climbing up a chimney to escape the rebels, a feat which would have been quite difficult on a night when temperatures were in the thirtydegree range and the fireplace likely in full use. See Harold G. Hutcheson and Bernice Kames, We Call $\mathrm{h}$ Home: A Brief History of the West Fork of the White River Valley (West Fork: Washington County Observer, 1982), 35; Jacob M. J. Smith, diary entries for April, 1863, "Jacob M. J. Smith Journal, 1842-1886," manuscript, Special Collections, University of Arkansas Library, Fayetteville. 
of Mount Sequoyah. Tin Cup, as the neighborhood along the ravine later became known, runs almost due south along the base of the mountain, fed by the original spring that led to the town's founding by William McGarrah in 1828. Shortly before Cabell's men turned up the ravine, some Federal sentinels posted in a rifle pit south of town spotted the invaders and opened fire. These pickets were quickly overwhelmed, and at about 6:00 A.M. the battle of Fayetteville began.

As we reconstruct the ship within a bottle that represents the battle of Fayetteville, we can add many particulars about the incident that have been previously overlooked. ${ }^{20}$ First, an amazingly detailed map of the battle omitted from Colonel Harrison's official published report has been preserved by the National Archives. ${ }^{21}$ The map pinpoints precise locations for houses, churches, stores, and the opposing forces on the battlefield. Second, some jealous subordinates accused Colonel Harrison of cowardice following the battle, and their charges, along with Harrison's answers, have been found in his compiled service record. ${ }^{2}$ The courtmartial charges (which were so flimsy they apparently never resulted in a hearing) allows present day investigators to place individuals and units at various locations on the field that are not readily apparent from Harrison's published official report. Finally, the reminiscences of Lt. Elizur B. Harrison, Dr. Seymour D. Carpenter, and Sarah Yeater can now be compared for corroboration with the map and courtmartial charges.

${ }^{20}$ Wendell P. Beall, "Wildwood Skirmishers: The First Federal Arkansas Cavalry" (M.A. thesis: University of Arkansas, 1988), 166-183; Joe Fears, "Standing in the Furnace of Rebellion: The Story of the First Arkansas" (Fayetteville, 1986), 87-96, typescript photocopy, Special Collections Division, University of Arkansas Library, Fayetteville; Walter Lemke, "The Battle of Fayetteville," Flashback 13 (May 1963): 39-42.

${ }^{21}$ "Battle of Fayetteville, Arkansas, April 18, 1863," map, National Archives and Records Administration, Record Group 94, Union Battle Reports, Box 37. Special thanks to Dr. William Shea, University of Arkansas at Monticello, for bringing this map to my attention.

${ }^{2}$ M. LaRue Harrison to John M. Schofield, June 27, 1863, in Compiled Service Records of Volunteer Union Soldiers who Served in Organizations From The State of Arkansas, National Archives Microform Publications, Microcopy 399, Record Group 94; cited hereafter as Compiled Service Records. 
Needless to say, the initial skirmish and subsequent deployment of nine hundred Rebel soldiers that cold April morning could hardly have been executed in silence. Among the many Fayetteville residents who recognized the danger in the sounds echoing up from the Tin Cup ravine were Sarah Yeater and Lt. Elizur Harrison. Sarah had been ill for several days, confined to her bed in the little shack behind William Baxter's house. That Saturday morning she felt particularly weak, and she barely stirred when her mother-in-law burst into the room with the news that the Rebels were about to attack.

"Let them come," Sarah replied apathetically, "I'm too sick to get up." Mrs. Yeater left her daughter-in-law for a moment, but then quickly returned with her daughter, Sallie, to gather up Sarah and her boy, Charley. The Yeaters also took the bedding from the room and fled across the yard to the cellar of the Baxter home where they were joined by the Davis family and several servants. ${ }^{23}$

Upstairs in the house Lieutenant Harrison got up after hearing what he later described as an "unusual noise" and dressed quickly. While struggling with his clothes, he looked out the back door, which faced east towards Mount Sequoyah, and caught sight of the Rebel cavalrymen scurrying into position. Harrison slammed the door shut and hurried out the front entrance to Cassville Road in order to avoid directly crossing Old Missouri Road to his brother's command headquarters in the Tebbetts house. Fortunately Colonel Harrison had already left headquarters. He met his brother on Cassville Road where they were partially screened from the converging enemy forces. Together the two officers ran northward towards the main camp of the garrison. There they found both regiments, the 1st Arkansas Cavalry and the 1st Arkansas Infantry, assembling under the screaming commands of the company officers. ${ }^{24}$

While the Federals hastened to receive the attack, General Cabell accompanied the artillery along a road further up the western slope of Mount Sequoyah, which parallelled Tin Cup ravine. ${ }^{25}$ Ironically the general and his guns crossed almost directly over the future site of Fayetteville's Confederate Cemetery, where many in his command would

\footnotetext{
${ }^{23}$ Yeater, "Civil War Experiences," 21.

${ }^{24}$ Harrison, "Battle of Fayetteville," 17.

${ }^{25}$ This road is roughly the present route of Summit Avenue on Mount Sequoyah.
} 
find their final resting place that day. Cabell raced north along the road with an escort from Capt. Joseph P. Weir's Texas cavalry company to assist in the support of Captain Hughey's battery. The force halted once they had reached a point where they could get the range of the Federal encampment, just above the former home of Thomas Montague Gunter. ${ }^{26}$

The woods stretched out below the general, extending down into Tin Cup ravine and up almost to William McGarrah's farmhouse. ${ }^{27}$ Beyond McGarrah's house Cabell could see open ground leading to the intersection of the Cassville and Old Missouri roads, with the house of William Baxter and the Yeater's shack sitting back from the southeast corner. ${ }^{28}$ The general also could see the Tebbetts home, set back just as far from the northeast corner. The house was surrounded by a dense hedge, and beyond it was a board fence. On the northwest corner of the intersection stood the charred foundation wall of the Fayetteville Female Institute, which had burned in February 1862. That morning only a small smokehouse, used by the Union forces as an arsenal, remained at the rear of the lot. To the north of the Female Institute ruins Cabell could see the Moore house, the Brannan house (Sallie Yeater's former home), the Lee house, and Sarah Yeater's old house, which presently served as headquarters for the 1st Arkansas Cavalry. Behind it, on the eastern slope of Mount Nord, stood the camp of the regiment itself where more rifle pits could be seen frowning from the summit. On the southwest corner of the Cassville and Old Missouri roads stood two residences, of which the northernmost was used as the ordnance office for the garrison. ${ }^{29}$ General Cabell took careful note of both the arsenal and ordnance office; possession of them would be the key to victory once he had demoralized the garrison with his opening shots.

\footnotetext{
${ }^{26}$ In addition to the map's placement of the guns in this position, the trajectory of fire from the cannon can be determined by the two known impact points: the Baxter house and the arsenal (smokehouse) near the corner of Highland and Dickson sreets.

${ }^{27}$ Presently the site of the Fayetteville Public Library.

${ }^{23}$ Presently the parking lot of the Washington County Courthouse annex.

${ }^{29}$ Elizur B. Harrison's memory in 1926 complemented the map his brother had drawn in 1863. See: E. B. Harrison, "Fayetteville at the Time of the Civil War" Flashback 18 (August 1968): 19-20.
} 
As Cabell ordered a few companies of dismounted men to rush along Center Street in order to deploy as skirmishers north towards the arsenal, the Confederate artillery began to unlimber. Captain Hughey directed the placement of his guns just as a few puffs of smoke appeared from the houses almost a quarter mile below. In a frank demonstration of the possible range from Federal small arms fire, a bullet struck the Captain's arm before he could even put his battery into action. In spite of the wound, Hughey ordered the guns to be trained on the enemy's camp on the west side of Cassville Road and to open fire..$^{30}$

Meanwhile Colonel Harrison directed the ranking infantry commanders, Lt. Col. Elhanon J. Searle and Maj. Elijah D. Ham, to move most of the civilian-clad Union footsoldiers to a sheltered position on the western slope of Mount Nord in order to avoid having the Federal cavalry troopers shoot their comrades by mistake. Searle and Ham began the orderly withdrawal of their men just as the southern artillery shells began to rain down upon them. The terrific explosions and the screams of the wounded horses had an unnerving effect on green infantry recruits, and about thirty men began to break ranks. Among those who bolted north towards Missouri along Cassville Road was none other than Lt. Crittenden C. Wells, the same officer who had so callously threatened William Baxter that past February. His flight would result in his dismissal from service a few months later. Most of the 1st Arkansas Infantry did as they were told and removed themselves to the western slope of Mount Nord, safe from the Rebel artillery. ${ }^{31}$

As the main body of Union infantry withdrew, Capt. DeWitt Hopkins and Lt. William Messinger of the 1st Cavalry approached Colonel Harrison in obvious agitation. With the Rebel skirmishers threatening from the south and Cabell's artillery pounding the camp, Hopkins and Messinger explained they believed the battle to be already lost. The colonel rebuked them angrily. "Can we retreat, they on horses and us on foot?" he demanded. The subalterns replied in the negative once they considered the pitiful number of horses available for flight. Colonel Harrison continued, "Do you wish to be disgraced by surren-

${ }^{30}$ Little Rock True Democrat, April 29, 1863.

${ }^{31}$ Presently overlooking Fayetteville's Wilson Park. 
der?" Again the junior officers replied, "No." "Then let us fight it out to the death," proclaimed Harrison as he lit a cigar. Calmed by their leader's resolve, Hopkins and Messinger saluted smartly before returning to their men. There would be no Prairie Grove-style stampede this day. ${ }^{32}$

Harrison placed companies A and I under the command of Maj. Ezra Fitch and sent them double-quick down to the Female Institute's ruins to hold the ground, drive in the Rebel pickets near the hospital on Center Street, and protect the garrison's arsenal. Capt. Randall Smith, commanding Company A, 1st Arkansas Infantry, reported for orders, and Harrison sent him to the south to join Fitch's battalion. This left three companies of infantry, $\mathrm{E}, \mathrm{H}$, and $\mathrm{F}$, to be retained as a reserve as the colonel organized the rest of his force to meet the Rebel attack. Harrison needed every man he could get, for by sending the bulk of the infantry out of harm's way, he had no more than $\mathbf{5 0 0}$ men to meet the onslaught of an enemy he had yet to see in full force. Cabell's men enjoyed only a slim numerical advantage; because of the need for the standard reserve of horseholders (every fourth man), the Rebel commander could not commit to battle any more than 625 dismounted men out of his total force of 900 .

Seeing the desired effect of his artillery on the enemy's camp, Cabell ordered his men forward from their sheltered position in Tin Cup ravine to take the strategic ground around the buildings west of the Cassville and Old Missouri Road intersection. Leading the assault were Col. James M. Monroe and Capt. Oliver Basham. Basham had remained mounted when the others took to the ground; because of his bulk he feared he would be unable to keep up. As they broke into the open ground, some of the troopers around Basham urged him to dismount, for the Federals began to return fire rapidly from several of the houses ahead. Reluctantly Basham swung his huge frame out of the saddle, and the moment his feet touched the ground, a bullet grazed the knuckles of his hand still resting on the pommel of his saddle. Had he remained seated a moment longer the ball would have entered his stomach. ${ }^{33}$

\footnotetext{
${ }^{32}$ Harrison to Schofield.

${ }^{33}$ Little Rock True Democrat, April 29, 1863.
} 
The Confederates gave the traditional Rebel yell as they hurled themselves forward, obviously hoping the combination of shock assault with artillery fire would cause the flight of Lieutenant Wells and the others to grow into a general stampede. Such was not the case, however, and as they closed in on the McGarrah, Baxter, Yeater, and Tebbetts houses, they continued to receive fire from a few Federal occupants who refused to evacuate. The resistance, unexpected as it was sharp, wounded several Confederates as they attempted to advance on the Baxter house. General Cabell noticed the puffs of smoke issuing from an upstairs window of the house and dismounted to aim the howitzer directly at the offending building. ${ }^{34}$ Apparently the general had paid good attention to his West Point artillery instructors, for the shot landed in the structure as aimed. The shell had little effect on the armed defenders because it passed on into the basement where Sarah Yeater was hiding with the other women and children. There the miraculous failure of the shell to detonate temporarily saved most of the building's occupants from harm.

Although the Davis women had gone to the cellar with the Yeaters, Ben Davis (a man described by Sarah in obvious understatement as "not mentally strong") had remained upstairs. After the enraged Rebel cavalrymen burst into the house and dispatched whatever Federal soldiers still defended the place, Ben attempted to grab one of the Confederates to explain about the women hiding below. The officer shot him without ceremony, and Davis crawled mortally wounded down into the cellar to join the women. As Sarah listened to the battle sounds pounding overhead and Ben's gasping explanation as he lay bleeding on the floor, she heard yet another call for help from a wounded man upstairs. One of the Federal soldiers who had survived the attack also wished to crawl to safety, and the terrified women managed to pull him, too, into their dark and crowded refuge. ${ }^{35}$

As the Rebels forced their way into the buildings on the east side of Cassville Road, Colonel Harrison organized his forces for a general advance behind the houses on the west side of the street. He took personal command of the center and moved directly south, leading his

${ }^{34}$ Ibid.

${ }^{35}$ Yeater, "Civil War Experiences," 22. 
men behind the Lee, Brannan, and Moore houses until they arrived at a position adjacent to the hedges and fence surrounding the Tebbetts house. The left wing under the command of Lt. Col. Albert W. Bishop blasted away at whatever skirmishers they saw in McGarrah's wheat field, the parade ground of the Union regiment. The Rebels could not get close enough to deliver fire effectively with their shotguns from such an exposed position and fell back to the trees near Old Missouri Road while Bishop's men used the superior range of their own carbines to push the enemy before fanning out on the open ground..$^{36}$

Cabell observed some of these movements from his vantage point by the artillery. Somewhat bewildered that the Federals were making a stand, he tried to again demoralize the enemy with artillery fire. Hughey's battery lobbed another shell in the midst of Harrison's right wing as they deployed, catching a luckless private of Company I, James D. Bell, directly through the body as he stood next to the arsenal smokehouse. Rather than panic, the troopers under Major Fitch took position behind the foundations of the Female Institute and coolly returned the fire which poured at them from the Baxter house and the grove of trees on the Arkansas College grounds to the south. Hughey's battery delivered no more shells on this portion of the field, probably because the gunners were reluctant to fire over the heads of their own comrades and perhaps because they had been informed by now that civilians were hiding in the houses below. ${ }^{37}$ Another plausible explanation for the artillery's silence at this point in the battle is that they had

\footnotetext{
${ }^{36}$ Bishop's wing advanced to a position roughly between present-day intersections of Lafayette and Washington on one end and Maple and Willow on the other.

${ }^{37}$ One southern observer says that women appeared in the windows of their houses to wave handkerchiefs in encouragement to the southern forces. If this actually occurred in the midst of a battle, the motivation of the women may have been to beg the soldiers to stop shooting. See Washington Telegraph, Washington, Arkansas, April 29, 1863. It should be pointed out here that it would have been impossible for soldiers fighting at the College and Dickson Street intersection to distinguish the sound of artillery fire from the small arms. At a reenactment of the battle held on April 17, 1994, a mountain howitzer was fired from the identical location on Mount Sequoyah with a double charge of powder. The sound was audible to spectators gathered at the intersection below, but was hardly what anyone present would have considered loud. This reenactment occurred on a quiet Sunday afternoon with very little modern traffic noise and no wind.
} 
little else to shoot at. A modern-day survey of the battlefield from the rebel artillery position shows a very limited range of fire to the north of the Tebbetts house. In order to deliver effective shots to the Union soldiers in McGarrah's wheat field, Cabell would have had to advance the guns north along the mountain road to find a suitable position. Fortunately for the Federal troops, their left wing, under the command of Lt. Col. Bishop, already held an ideal position on the field to check such a maneuver by the Rebels.

Even though he laughed among his men and tried singing a few patriotic songs to keep them calm, Colonel Harrison worried about a possible flanking movement from the north across McGarrah's field..$^{38}$ Such an advance could cover a simultaneous movement of the Rebel artillery, and Harrison determined to silence the battery before it could be moved to threaten his left wing. After the Federal commander led the center companies through the hedge behind the Tebbetts house and regained possession of the structure itself, he sent his brother to order someone from the left wing to flank the enemy first by approaching them from the north. Lt. Harrison ran to deliver his brother's orders to either Lt. Col. Bishop or Maj. Thomas J. Hunt, but the task became extremely hazardous once the firing began again on the north part of the field. Captain William M. Johnson, Company $\mathbf{M}$, had his right arm shattered by an enemy slug, and the Texans assigned to support the Rebel battery kept up a hot fire from the brush with their pistols and shotguns to check temporarily the advance of the left wing. First Sgt. William M. Burrows of Company $\mathrm{E}$ fell wounded during this exchange and reportedly told comrades who attempted to carry him to safety to return to the fight. ${ }^{39}$

Lieutenant Harrison made his way along the battle line's left wing until he found Lieutenant Robb of Company $L$ and informed him of the colonel's desires. Robb wasted no time in ordering his company forward in skirmish formation to attack the Rebel guns. The determined push forward by the Yankees unnerved some of the Texan defenders, and more horseholders fled, leaving their dismounted comrades stranded. ${ }^{40}$

\footnotetext{
${ }^{38}$ Harrison to Schofield.

${ }^{39}$ Albert W. Bishop, report to M. LaRue Harrison, April 19, 1863, Regimental Records.

${ }^{4} O R$, ser. I, vol. 22, pt. I, 312.
} 
At least one member of Robb's command, Pvt. Hugh Cook, found the advance too slow and ran forward to disappear into the thick woods two hundred yards ahead. He reappeared a few moments later leading two Texas cavalry mounts, explaining that he had shot the horseholders and captured their arms. ${ }^{41}$ When Robb had moved his men as far as the treeline, he ordered several volleys directed at the smoke that disclosed the position of the artillery farther up Mount Sequoyah. Bullets from the long-range guns whistled through the trees, smashing into men and horses hundreds of yards away. One of the gunners fell dead and several men and horses suffered wounds. ${ }^{42}$ The fire proved too hot to stand, and when Captain Hughey reported to General Cabell that he had nearly exhausted his ammunition, Cabell ordered the pieces withdrawn and sent back down the road by which they had come.

Back at the intersection, the Union forces had regained possession of all the structures on the north side of Old Missouri Road and were able to extend the right wing south to cover the ordnance office and other buildings across the street from the Arkansas College grounds. Rebels still held the Baxter house, and even though they continued to retire to Tin Cup ravine to reform their ranks, the Confederates tried several times to complete their push towards the arsenal. (During several of these dismounted charges, the defenders suffered more casualties. In their exposed position by the Female Institute, more soldiers fell from Company A than any other Federal unit on the field that day.) Colonel Harrison moved from point to point, checking on the men, ordering the sergeants to make sure of the men's ammunition, and exposing himself so recklessly that his son begged him to get down. ${ }^{43}$ The boy had been close to his father all morning, firing away at the enemy with a revolver and a carbine that matched his diminutive height. ${ }^{44}$ Since the Rebel's shotguns could not send effective fire beyond a few dozen yards, the

\footnotetext{
${ }^{41}$ Bishop to Harrison.

42John Q. Anderson, ed. Campaigning with Parsons' Texas Cavalry Brigade, C.S.A.: The War Journals of the Four Orr Brothers, 12th Texas Cavalry Regiment (Hillsboro, TX: Hill Junior College Press, 1967), 99; Little Rock True Democrat, April 29, 1863.

${ }^{43}$ Harrison to Schofield.

${ }^{4}$ Bishop to Harrison.
} 
determined blasts from the Union cavalry's rifled carbines kept the Confederates at bay near the Baxter house.

The battle had been raging for about three hours. During that time Cabell had exhausted his artillery ammunition, lost a number of horses from rifle fire and the unreliability of the holders, and had even given up what little ground his army gained during the initial attack. He still could not understand how these Arkansas Federals could stand against his liberating forces and may have believed that his sustained attacks had pushed Harrison's men close to panic. Cabell quickly ordered most of his command to remount, committing several hundred available soldiers to a desperate charge. As pointed out previously, by remounting his command, Cabell could add an additional 275 soldiers to his assault and hope that the sheer numbers would inspire another stampede to Missouri like that of Lieutenant Wells and his comrades earlier in the morning.

Cavalry is best used as a punishing strike against routed enemy troops, and the only logical explanation for Cabell's decision to use horsemen at this point in the battle is his sincere belief that the unprotected Federals would run, just as they had at Prairie Grove. Modern historians have accused some Civil War commanders of employing obsolete tactical maneuvers by way of refusing to adapt to the midnineteenth century improvement of rifled firearms. Other writers have argued that soldiers in the 1860 s had a respect for fieldworks and fortifications that may have surpassed their actual military value. ${ }^{.5}$ Both of these generalities can be illustrated by the Confederate actions at Fayetteville, because the defeat of the attackers can be partially explained by the psychological impact of rifle pits and the deadly accuracy of enemy fire from rifled carbines. Even though all surviving Confederate accounts of the battle mention rifle pits as if they played a major role in the Union garrison's successful resistance, the truth is that on most of the field there were no prepared defensive works whatsoever. In spite of his orders, Colonel Harrison had really done very little in constructing fortifications in Fayetteville other than putting a few rifle pits on Mount Nord and at the picket posts leading out of town. If there had been

"Saddy Griffith, Battlefield Tactics of the Civil War (New Haven: Yale University Press, 1989). 
prepared breastworks at the intersection of Cassville and Old Missouri Roads, a mounted cavalry charge would have been the last tactical option chosen by an attacking commander.

At the intersection Major Fitch made sure his men took advantage of what little opportunity they did have to cover themselves, especially around the foundation walls of the Female Institute. Near the ordnance office surgeon Seymour D. Carpenter paused a moment in his efforts to remove the wounded in order to watch Fitch with a vague feeling of contempt. The doctor always considered the major somewhat of a dolt and had seen nothing so far this morning to change his mind. As Fitch strode among his sheltered troopers with an ostrich plume hanging limply from his slouch hat, Carpenter amused himself by thinking how much the officer reminded him of a slow-witted turtle. ${ }^{46}$

Lt. Elizur Harrison hurried back from the left wing once he had observed Company L carrying out his brother's orders. Cutting diagonally across McGarrah's field he reached a large tree that stood near Cassville Road on the corner of the Tebbetts lot. ${ }^{47}$ From this vantage point he saw the dramatic results of General Cabell's last desperate gamble to win the battle of Fayetteville.

Colonel Harrison, standing directly behind Company F posted to the west of the Tebbetts house, felt the imminent threat of a great assault. Pulling his cigar from his mouth he took advantage of the temporary quiet to speak to his men. "Aim low, boys," he shouted, "take good aim and be sure to kill a man every time. ${ }^{\text {"48 }}$ These were not idle words of encouragement; the battle had been raging for three hours, and with an average of less than forty rounds per man at the start, many cartridge boxes in the regiment were now dangerously low. ${ }^{49}$

Over near the ordnance office, Dr. Carpenter also sensed something stirring from the ominous lull in the fighting. He glanced at Major Fitch, who walked up and down behind the line of the crouching troopers of Company A. Fitch waved his pistol at Capt. Randall Smith, urging him to place his line across Old Missouri Road and around the ordnance

${ }^{46}$ Carpenter, Genealogical Notes, 142.

${ }^{77}$ Presently the northwest corner of the SWEPCO building parking lot.

${ }^{4}$ Harrison to Schofield.

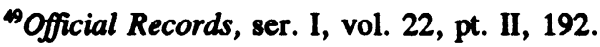


office. The major's energy surprised the doctor, and a grudging respect began to replace Carpenter's earlier feeling of disdain for the cavalryman.

Suddenly a bugle sounded, and the jingling of harness and saber from Rebel cavalry echoed up from Tin Cup ravine. A thundering of hooves shook the ground, and Lt. Harrison watched awestruck as the charge of Rebel cavalry in column swept down Old Missouri Road in a swirl of dust and gunsmoke. Tennyson's refrain, "Into the valley of Death rode the six hundred," played upon the lieutenant's thoughts, mainly because the narrowness of the street funneled the daring horsemen into a compact target for the waiting Union forces ahead at the intersection. ${ }^{50}$ Dr. Carpenter, too, saw the charging grey-clad troopers too, and he watched Major Fitch jump to the front of the battle line, waving both hat and pistol as he exposed himself to the onrushing attack. Dr. Carpenter felt a rush of admiration for Fitch as the major swore mightily and ordered his men to "give 'em hell!"s1

When the first rank of Rebel cavalry reached a point about forty yards from the intersection, roughly parallel with the Tebbetts house, a tremendous volley of carbine fire erupted from the Union line. Down went the foremost riders in a tangled mass of horses, weapons, and men. Falling from his horse with an agonized scream was Maj. Hugh G. Wilson, the Confederate force's commissary officer, who had caught a slug which penetrated his thigh and exited at his spine. One horse, shot through the body, gave a tremendous leap that cleared William Baxter's wooden fence before crashing dead in the yard. The rider managed to recover from his flight, disengage himself from the animal, and crawl to the rear of the Baxter home, which was temporarily safe from the Union crossfire.$^{52} \mathrm{~A}$ few pistol shots from the Rebels replied to the volley, and Captains Randall Smith and William Parker, the infantry officers on Fitch's wing, were both hit in the head by stray bullets.

The pileup of mangled horses and men at the intersection prevented the rest of the Rebel column from pushing forward. The horses veered

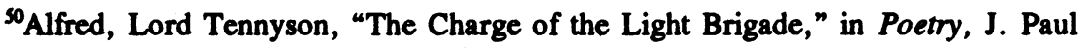
Hunter, ed. (New York: W. W. Norton, 1973), 19.

${ }^{51}$ Carpenter, Genealogical Notes, 142.

${ }^{52}$ Harrison, "Battle of Fayetteville," 18. 
off to the left, heading directly south on Cassville Road before cutting across the Arkansas College grounds to the southeast. ${ }^{53}$ Much to the surprise of the Confederates, Major Fitch's men did the reverse of what they had expected. Instead of running in terror from the continuing charge, some of the Federals put down their empty carbines, drew their revolvers, and chased the survivors down the street with a chorus of curses and pistol fire. One trooper, Sgt. Ruben S. Haley, managed to drop the Rebel's color bearer with a well-aimed shot, and within seconds the last of the grey-clad horsemen disappeared. Now the victors came forward to view the results of their carbine volley..$^{54}$

Colonel Harrison gazed through the pall of gunsmoke at the destruction of humanity and horseflesh writhing in the intersection. Already Dr. Carpenter had run forward to offer what assistance he could to the fallen, ordering men to pull the wounded back to the porch of the ordnance office and give water to those who begged for it. Lieutenant Harrison was among the soldiers who ran forward with canteens to help their now conquered enemies. The colonel turned away, however, and ran back to the Moore house to bring up the infantry reserves posted there. Although the field had fallen silent again, there could be no assurances the battle was over. ${ }^{55}$

General Cabell's desperate gamble had failed. He watched the survivors of Monroe's regiment limp down to the lower part of Tin Cup ravine with the heavy realization that Fayetteville would remain in Federal hands this day. Still, the aggressiveness of the Union resistance disturbed the southern commander, and he convinced himself that the enemy's courage had come mostly from the advantages they enjoyed from their defensive position. Partly to cover the retreat of his horsemen and partly to attempt drawing the defenders to a more exposed area, Cabell again deployed dismounted skirmishers west of the Arkansas College grounds to fire north at Major Fitch's wing.

Once Colonel Harrison heard the popping to the south, he ordered Captain John McCoy of Company F, 1st Arkansas Infantry, to move his men closer to the Tebbetts house. Harrison then went inside the Moore

${ }^{53}$ Presently the site of the First Christian Church.

S4Bishop to Harrison; Carpenter, Genealogical Notes, 142-143.

${ }^{35}$ Harrison to Schofield. 
house, where he found several skulking enlisted men from his own regiment. Ordering them outside at the point of his revolver, the Colonel called for Lt. Cyrus Wills to take charge of the men and report to Fitch. The gunfire continued as the Federal commander returned to the center of the Union lines. Finding Capt. Dewitt Hopkins, Harrison ordered him to take Company I south towards the hospital and shoo away the Rebel skirmishers. ${ }^{56}$

In the street the wounded Confederates were being moved to more comfortable positions. Dr. Carpenter ordered one loudly complaining Confederate to the porch where he hurriedly dressed the soldier's wound; the middle finger of the hand had been shot off. To the doctor's astonishment, the trooper died shortly thereafter. In his haste Carpenter had not realized the poor fellow had also been shot in the stomach and was slowly dying of an internal hemorrhage while the physician bandaged his hand. ${ }^{57}$

The Rebel army reformed on the road heading south out of Fayetteville. Behind them lay nine dead men at the intersection, probably two dozen more in other parts of the field, and about fifty wounded. When it became obvious that no pursuit would be forthcoming from the Federal garrison, Cabell leisurely formed his expedition, counted his losses, and moved slowly off towards Ozark on the Huntsville road. Two surgeons were sent back to care for the wounded, while the balance of Cabell's force began the long trek back to the Arkansas River valley. Colonel Harrison could not pursue. Only 122 horses remained on their feet, and the Federals still grappled with the fallen men as they attempted to reform their own ranks. The way Harrison viewed it, his men still held the field, but the victory left them in no condition to win the day.

As midday approached it became obvious that the battle had ended. Sarah Yeater came up from the cellar to view the carnage and return to her home. Badly shaken from the experience, Sarah had found the defused artillery shell lodged directly under the pallet on which she had been lying. When she returned to her bed in the little house behind Baxter's, she discovered the place to be riddled with bullet holes, several

\footnotetext{
${ }^{56}$ Ibid.

${ }^{57}$ Carpenter, Genealogical Notes, 143.
} 
of which had entered the mattress. If she had followed her first inclination that morning and remained in bed with Charley, both would certainly have been killed..$^{58}$

Sallie Yeater also came up to the daylight, where she saw the Union soldiers working with the wounded out in the street. Watching Lieutenant Harrison carrying water for the prostrate Confederates still waiting for the surgeons warmed her heart, even though she had been an ardent defender of the secessionist cause. Within a year the southern girl would marry the northern officer, partly as a result of the kindness she saw him extend to the fallen foe that April morning. ${ }^{59}$

Colonel Harrison slowly made his way down Cassville Road to Washington L. Wilson's home on Center Street. ${ }^{60}$ Although shaken by the fight, a wild elation began to grow inside the Federal commander as he ate his breakfast at the house. His command alone had beaten off a surprise attack, and the stigma of the 1st Arkansas Cavalry's flight at Prairie Grove could now be erased. Harrison began making out a proclamation to the men to be read publicly the next day:

I congratulate you that this battle was fought upon Arkansas soil, and this victory won by Arkansians alone ... but in our rejoicing let us not neglect to shed the tear of regret over the graves of those heroic men who fell beside us fighting bravely for the nation's honor.

Green be their mossy graves

Immortal be their name;

Above, their banner proudly waves

While heaven records their fame! ${ }^{61}$

The next morning, while issuing the congratulations to the post, Colonel Harrison received a visit from Capt. William A. Alexander of Company C, Monroe's Arkansas Cavalry, who arrived under a flag of truce to see

${ }^{\text {S8} Y e a t e r, ~ " C i v i l ~ W a r ~ E x p e r i e n c e s, " ~ 22-23 . ~}$

${ }^{59}$ Lila Harrison, "Romance Born of Battle," Flashback 18 (April 1968): 20-21.

${ }^{60}$ Harrison to Schofield.

${ }^{61}$ M. LaRue Harrison, General Orders No. 16, April 19, 1863, Regimental Records. 


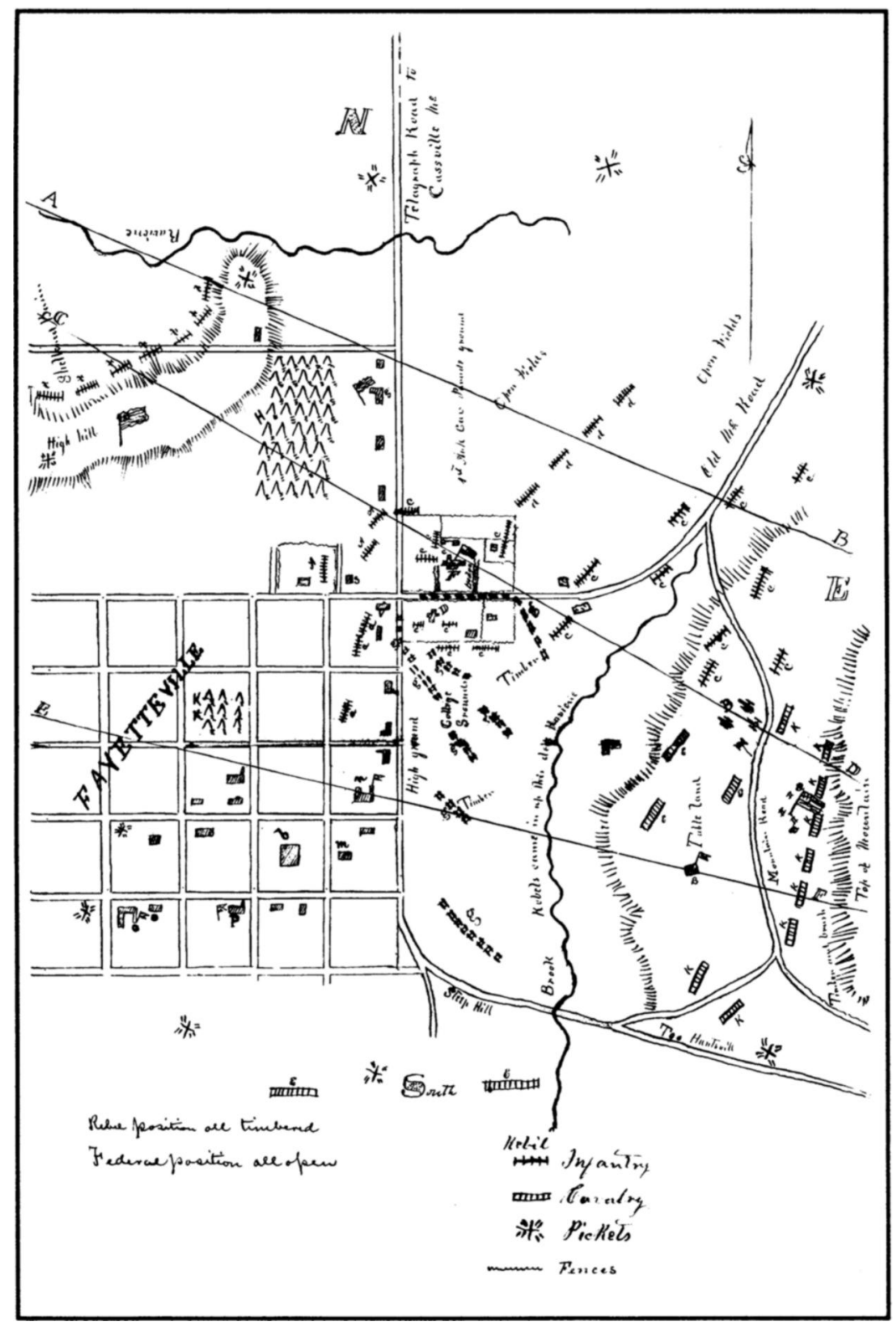

Battle at Fayetteville. This map was likely drawn by Colonel Harrison himself to accompany his official report. Courtesy National Archives and Records Administration. 


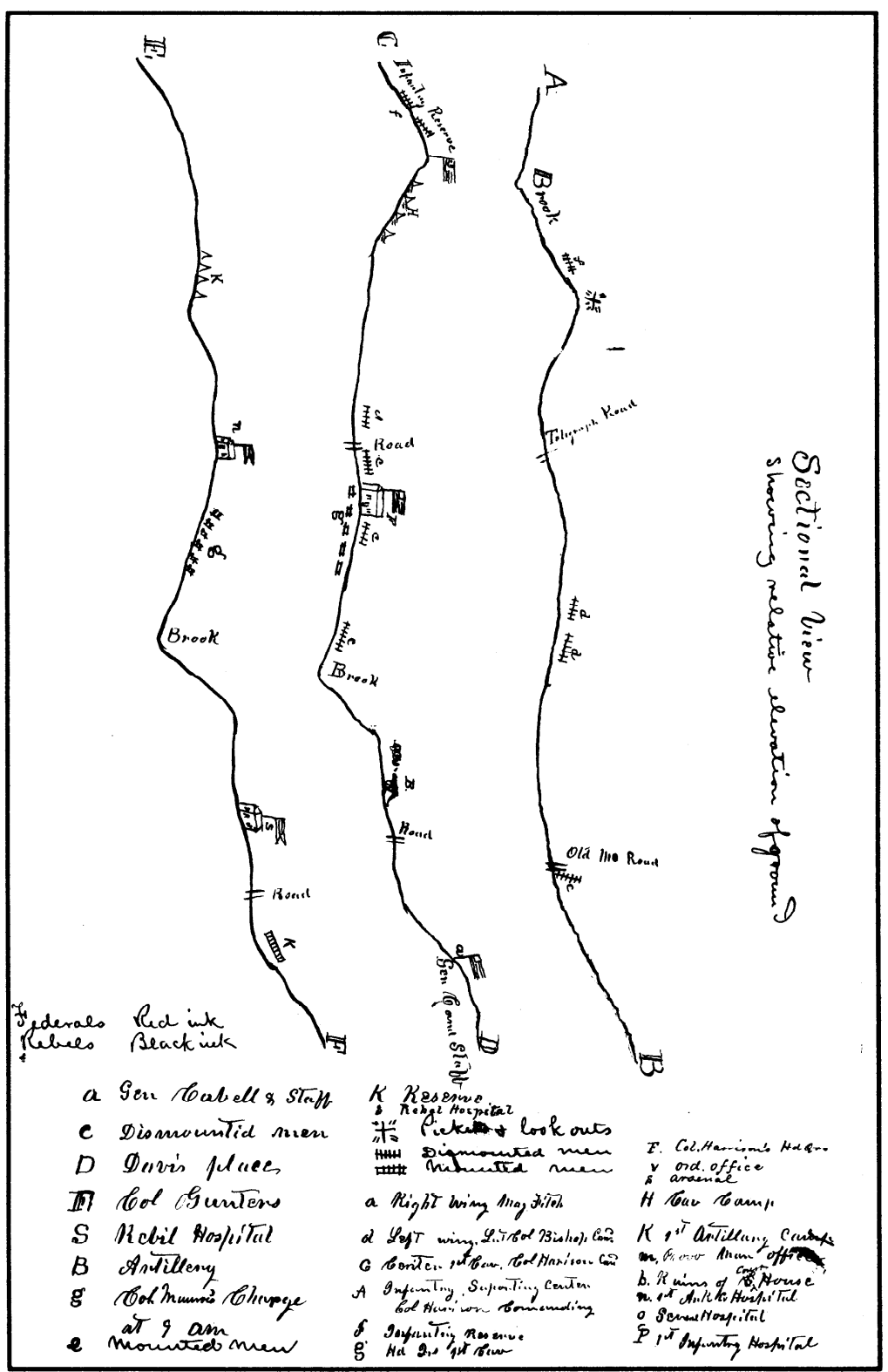

Sectional view showing relative elevation of ground. Courtesy National Archives and Records Administration. 
to the disposition of the southern dead and wounded. Colonel Harrison proudly showed his visitor that his command had decently buried their fallen enemies in coffins, and that the two surgeons General Cabell left behind worked side by side with their northern counterparts, sharing the same medicines and supplies.

With the meticulous placement of miniature rigging and sails, a tiny ship in a bottle grows to represent a much larger vessel. While reconstructing the details of Fayetteville's 1863 ordeal, we have also built within a bottle a tiny replica of the Civil War. Arkansans of opposite allegiance spilled each other's blood in a place both called home, just as thousands of Americans did likewise on the fields of Virginia, Maryland, and Pennsylvania. The sufferings of Jonas Tebbetts, William Baxter, and Sarah Yeater reveal in intimate closeup the similar ordeals of many civilians across the South during the Civil War. Following the route of General Cabell's rapid march to Fayetteville while using the terrain to confuse a Union patrol allows us to appreciate the larger movements of Confederate strategists while dueling with Mr. Lincoln's army in the east. While recognizing the profound impression that even superficial fieldworks had on Cabell's army in Fayetteville, we can understand the snail-paced advance of Gen. George McClellan on the Peninsula. The murderous effect of rifled guns on Colonel Monroe's hopeless charge down Old Missouri Road can be seen as a small-scale Pickett's Charge, while Colonel Harrison's reluctance to pursue his badly mauled opponent to seal the victory echoes General George Meade's exhausted cloture to the bloodletting at Gettysburg.

But the real tragedy of the Civil War, the unnecessary sacrifice of so many lives for a cause that both felt just, is the final lesson of the battle of Fayetteville. On April 25, 1863, Col. M. LaRue Harrison responded to orders from his superiors and abandoned the post at Fayetteville. In the days following the battle, the Union high command decided that it would be impractical to reinforce Fayetteville after Harrison successfully argued that he lacked sufficient strength to hold it. Nine Union soldiers had given their lives to defend the town; another twenty-four were maimed. But now the Federal garrison simply walked away from the scene of their hard-won victory, and just eleven days later one of General Cabell's guerilla leaders, Captain Palmer, peacefully led his ragged command into Fayetteville without firing a shot. 